\title{
Entre enigmas e possibilidades:
} configurações detetivescas nos romances As iniciais, de Bernardo Carvalho, e O silêncio da chuva, de Luiz Alfredo Garcia-Roza

\section{Between enigmas and possibilities: detective configurations in the novels As iniciais, by Bernardo Carvalho, and O silêncio da chuva, by Luiz Alfredo Garcia-Roza}

Taynara Leszczynski ${ }^{1}$, Maria Salete Borba ${ }^{2}$ Portuguesa) pela Universidade Estadual do Centro-Oeste (Unicentro), graduada em Letras (Português e Inglês) pelo Centro Universitário de Maringá (Unicesumar), especialista em Literatura Contemporânea pela Faculdade de Educação São Luís (FESL). E-mail: taynaraleszczynski97@hotmail.com. 


\section{Resumo}

Esta pesquisa adentra o campo da literatura policial, investigando de que maneira as configurações detetivescas modernas criadas por Edgar Allan Poe, fazem-se presentes, reinventando-se na contemporaneidade. Assim, para responder a essa questão, busca-se entender as configurações detetivescas modernas e analisar os romances policiais brasileiros As iniciais (1999), de Bernardo Carvalho, e O silêncio da chuva (2005), de Luiz Alfredo Garcia-Roza, para visualizar como essas configurações são postas nos livros. Destaca-se que o romance policial contemporâneo, apesar de manter muitas configurações modernas, não tem uma estrutura fixa e linear, dividindo-se em duas áreas: o whoddunit e o roman noir.

\section{Palavras-chave}

Literatura brasileira contemporânea, romance policial, detetive.

\section{Abstract}

This study enters the field of detective literature, investigating how the modern detective configurations created by Edgar Allan Poe are characterized and reinvented in contemporary literature. For such, we verify what modern detective configurations are and analyze how the Brazilian detective novels As Iniciais (1999), by Bernardo Carvalho, and O silêncio da chuva (2005), by Luiz Alfredo Garcia-Roza, can be characterized as detective literature. Contemporary detective novels, despite maintaining many modern configurations, no longer have a fixed and linear structure, thus dividing itself into two types: whoddunit and roman noir.

\section{Keywords}

Contemporary Brazilian literature, detective novel, detective. 


\section{Breve panorama sobre a literatura policial}

A literatura policial foi inaugurada pelo escritor e crítico literário norteamericano Edgar Allan Poe no ano de 1841, com o conto "Os Assassinatos da Rua Morgue". O gênero literário criado por ele caracteriza-se por ser extremamente articulado, a partir de uma camada de suspense de natureza investigativa, repleta de enigmas e possibilidades. Essas características da narrativa policial são construídas mediante uma rede de configurações detetivescas intercaladas em um círculo criminal que estabelece uma ordem à narrativa.

Nesse mesmo contexto, em 1841, Poe também inventa o primeiro detetive literário da história, Auguste Dupin, o detetive moderno, como destaca Sandra Reimão (2005). Para a pesquisadora, essa personagem se assemelha à uma máquina de pensar, capaz de, apenas deduzindo, desvendar todos os crimes. Além disso, Dupin também foi um grande referencial para o surgimento de outras personagens famosas, como Sherlock Holmes, de Conan Doyle, e Hercule Poirot e Miss Marple, de Agatha Christie.

Segundo Reimão (1983), toda narrativa policial inicia-se com um crime ou um mistério e alguém disposto a desvendá-lo. Consideramos aqui que essas são as primeiras configurações, as quais desencadeiam as outras e formam a estrutura da narrativa policial: partindo do delito, tem-se os suspeitos, pistas e segredos, a serem investigados e desvendados pelo detetive, em um final fechado, no qual tudo é explicado de forma lógica. E essa fórmula narrativa de Poe pode ser entendida não só como o marco de nascimento de uma literatura policial, mas também como um padrão estrutural.

Jean Pierre Chauvin (2017), com base na leitura dos romances de Agatha Christie, salienta ainda dois momentos bastante usuais na narrativa policial: o primeiro, individual, consiste na investigação e descrição de cada personagem; e o segundo, em conjunto, se dá a partir de uma reunião com todos os suspeitos, na qual é revelado o método utilizado pelo criminoso para assassinar e, na sequência, é dito o nome do culpado e a motivação. 
O escritor argentino Ricardo Piglia (1986), diretor da "Série Negra", coleção de contos policiais, realça que as regras da literatura policial são movidas a partir do fetiche da inteligência pura. Valorizam-se, em primeiro lugar, a lógica e quem detém essa capacidade mental assídua. É o investigador que tem o trabalho de defender a vida burguesa, decifrando os enigmas, a partir de uma sequência de deduções e hipóteses, as quais relaciona às pistas, perfis dos suspeitos e, sobretudo, aos fatos, para chegar às verdades.

O autor também evidencia que, inicialmente, à literatura policial cabia o papel de suprir as deficiências das notícias policiais que se baseavam em uma simples narração de fatos. De acordo com o autor argentino, Poe fez isso com eficiência, pois está dos dois lados. Ele se afasta da realidade para dar abertura à ficção e a constrói em uma trama engenhosa, com traços que podem ser considerados verossímeis.

Nesse sentido, Paulo de Medeiros e Albuquerque (2007) dá ênfase à narrativa policial enquanto "[...] a primeira manifestação literária da inteligência humana" (ALBUQUERQUE, 2007, p. 2). Assim, é notável o porquê de elementos como a lógica, a estratégia e o raciocínio estarem sempre presentes nela.

Ademais, Adenize Franco (2013) considera que a ascensão do romance policial deve-se também ao surgimento do inspetor de polícia e a transgressão dessa figura pela mídia, em especial, em um período de guerra, que se espalhava para o Estado. Para ela, esse foi um grande marco da avalanche de consumo detetivesco:

No período entre guerras, surge o inspetor de polícia, assim como os crimes deixam de ser praticados apenas na esfera privada e alcançam $o$ Estado. Além disso, os crimes que atacam, em período da Guerra Fria, os espaços internacionais (especialmente o americano) constituíram temática no romance de espionagem, e com isso, outra categoria de detetive - vide os romances de um dos mais famosos agentes secretos do século $\mathrm{XX}$, James Bond, do escritor inglês Ian Fleming, ou do agente George Smiley, do britânico John Le Caré. (FRANCO, 2013, p. 80)

Além disso, a pesquisadora também avalia como importante, o surgimento do livro de bolso, "[...] com a revolução do livro de bolso a partir dos anos 50 torna-se mais fácil o consumo dessa ficção detetivesca" (FRANCO, 2013, p. 80). 
Já que o caráter popular da ficção só é atingido quando ela deixa de ser restrita somente à determinada camada social e chega ao domínio de um público maior, pertencente às diversas classes sociais.

Assim, percebe-se que desde seu nascimento, a literatura policial está inteiramente ligada ao desenvolvimento social, acompanhando as inovações e ideologias da sociedade. Como relata Piglia (1986), a figura do detetive é construída, em parte, a partir do real, principalmente, sob um viés estadunidense, em que grandes empresários contratavam detetives particulares, por sua alta habilidade investigativa, muito acima da polícia comum.

Outro aspecto importante é o financeiro. Segundo Piglia (1986), o dinheiro sustenta a moral e, consequentemente, a lei. Dessa forma, o detetive, geralmente, é visto como um profissional que exerce a sua profissão ou então alguém que adentra os casos pela recompensa. Entretanto, há ainda aquele que faz questão de negar qualquer pagamento, pois é atraído pelo mero desejo instigador de resolver um enigma, como o detetive de Poe.

Poe (2015) caracteriza a figura detetivesca como um gênio, dono de capacidades intelectuais que podem ser comparadas aos cálculos matemáticos, à estratégia e à tática do jogador de xadrez. Contudo, as suas capacidades intelectuais vão muito além disso, pois são pouco suscetíveis de análise, ou seja, não deduziríamos o crime, tal qual o detetive, o grande decifrador, pois não temos sua capacidade pensante, tampouco a entendemos, no entanto, nós a observamos e a apreciamos.

Walter Benjamin (1991, p. 38), por outro lado, ao referir-se à vida urbana, menciona que "[...] em tempos de terror, quando cada qual tem em si algo de conspirador, o papel do detetive pode também ser desempenhado". Essa afirmativa, apesar de não fazer jus ao gênero policial clássico³ , de Poe, Conan Doyle e Agatha Christie, no qual os detetives eram considerados gênios, é muito cabível nas narrativas policias contemporâneas, nas quais o meio pelo qual a personagem se configura como detetive acaba sendo diversificado. 
Há tanto o detetive de Poe, culto, inteligente e prático em deduções, quanto o detetive da polícia e seus vários casos fracassados e dificuldades. Existe também a pessoa comum, que por uma sequência de motivos acaba vivendo o papel de detetive, aquela que, por acaso, vive uma situação singular, como a morte de um conhecido ou o desaparecimento de algo ou alguém e, movida pela curiosidade e pelo instinto, considera-se hábil para desvendar o caso.

Além disso, Benjamin (1991) relata que, assim que os primeiros contos de cunho policial de Poe foram traduzidos para o francês, por Charles Baudelaire, impulsionou-se a reflexão acerca da complexidade desse gênero, tanto que o próprio Baudelaire, como constata o autor alemão, não ousou concorrer com Poe nessa escrita, mas o teve como referência em sua obra. Um exemplo disso é o flâneur ${ }^{4}$, o observador, que se torna detetive ao analisar e compreender a sociedade de sua época, assim como a personagem de Poe, em seu conto "O homem na multidão" (POE, 1999) que buscava decifrar os segredos e histórias presentes na sociedade urbana londrina, apenas observando cada indivíduo que passava em meio à multidão.

Dessa maneira, podemos pensar na narrativa policial como um jogo iniciado por um crime ou mistério e movido pelo desejo de esclarecê-lo. O objetivo é, portanto, solucionar o enigma "quem matou", a partir das pistas, fatos e suspeitos. O jogo é jogado por uma figura detetivesca ${ }^{5}$, que tem o papel de analisar todo o contexto e desvendar a charada, encontrando no final o criminoso.

\section{A literatura policial brasileira contemporânea}

Em um mundo em que a literatura se reinventa constantemente, como é configurada a narrativa policial na atualidade literária brasileira? O padrão criado por Edgar Allan Poe, referência ao romance policial brasileiro e mundial, ainda é seguido em meio a tantas inovações?

Baudelaire descreve o flâneur como um homem observador da multidão, no entanto a tradução literal para o português seria "preguiçoso". 
Marta Nebias (2010) destaca que faltam estudos e pesquisas sobre literatura policial, o que se deve à crítica literária brasileira, que acreditava que essa era uma literatura marginal. Desse modo, por sua popularidade, essa literatura não poderia ser foco de estudos, já que havia a ideia de que a leitura de boa qualidade era restrita a poucos.

Como realça a autora, por volta dos anos 1980 essa rejeição foi sendo superada e a literatura policial passou a ter um duplo alcance, tanto para o leitor comum, quanto para reflexões mais teóricas, mas ainda em baixa proporção. Ela considera o romance policial como fruto da ficção contemporânea "pós-utópica", ou seja, "[...] a época posterior ao modernismo, em que deixamos de ter um projeto literário e um adversário a ser combatido" (Nebias, 2010, p. 12). A pesquisadora também avalia que essa escrita pós-utópica se desenvolve em grande parte pela questão de proximidade entre escritor e leitor.

Podemos explicar esta recorrência do gênero policial também pela tendência atual da ficção brasileira, que passa a ter como marca uma relação mais próxima do escritor com a mídia e o mercado editorial, buscando um diálogo com a cultura de massa, na expectativa de reconquistar e reeducar o leitor comum. (NEBIAS, 2010, p. 5)

Não obstante, Chauvin (2017) assinala como errônea a afirmação de que sucesso de vendas implica falta de qualidade. Para ele, o que ocorre é que ao escrever sobre best-sellers, o crítico se coloca em uma posição arriscada em talvez dizer o que já foi dito ou parafrasear a obra. Contudo, o autor aponta que o texto literário sempre nos proporciona novos horizontes que fazem com que, muitas vezes, superemos as expectativas que tínhamos acerca da investigação inicial.

A literatura policial brasileira apresenta inúmeros personagens detetivescos, como por exemplo, Mandrake (1991), de Rubem Fonseca, personagem que virou série de televisão exibida em diversos países, e o detetive Pimentel, que povoou a literatura infanto-juvenil na coleção Vaga-Lume ${ }^{6}$ (1974). No entanto, como já 
apontado, a gama de estudos acerca deles é ainda rasa, tornando pertinente analisar de que forma a narrativa ou romance policial, ou ainda romance de enigma ou de detetive ${ }^{7}$, advinda de Poe, sob seu viés moderno, configura-se na produção literária contemporânea no Brasil. A fim de visualizar esses aspectos de forma mais profícua, selecionamos As iniciais (1999), de Bernardo Carvalho, e O silêncio da chuva (2005), de Luiz Alfredo Garcia-Roza.

É notável que a literatura policial brasileira contemporânea apresente diferenças em relação à de Poe, como cenários alternativos, personagens esféricos, desfechos abertos e, sobretudo, aspectos que remetem à tecnologia. Contudo, essa diferença é compreensível, ao observarmos que a literatura acompanha a identidade de sua época, como afirma Baudelaire "[...] uma literatura que se recusa a progredir de mãos dadas com a ciência e com a filosofia é uma literatura assassina e suicida" (BAUDELAIRE apud BENJAMIN, 1991, p. 40).

É pertinente sublinhar que os aspectos que se diferenciam, na contemporaneidade, em relação às obras de Edgar Allan Poe, Conan Doyle e Agatha Christie $^{8}$, fazem parte do processo literário, no núcleo de seu desenvolvimento, mas sem necessariamente ofuscar a permanência de uma estrutura da narrativa policial moderna. Vemos alguns desdobramentos, para novas construções detetivescas, mas que trazem ainda os elementos tradicionais policiescos, atualizados de acordo com as demandas da sociedade atual.

\section{A trama policial sob o silêncio da chuva: um caso de Espinosa}

Luiz Alfredo Garcia-Roza foi um escritor brasileiro, nascido em 1936, no Rio de Janeiro. Formado em Filosofia e Psicologia, atuou como professor na Universidade Federal do Rio de Janeiro (UFRJ), perpassou muitas áreas literárias, 
sendo uma delas a literatura policial. Nesse contexto, escreveu livro O silêncio da chuva, editado pela primeira vez em 1996 e considerado o romance policial de estreia do escritor, que recebeu prêmios, como Nestlé e Jabuti.

A grande criação de Garcia-Roza é um personagem peculiar, Espinosa, um inspetor de polícia que trabalha em uma delegacia localizada em Copacabana. Ele aparece em uma série de livros do autor, mas é em O silêncio da chuva, sua aparição inicial, que ele é retratado de forma mais humanizada. Há uma grande reflexão interior por parte do próprio detetive acerca de sua solidão, dificuldade de trabalho e brevidade da vida.

O Silêncio da chuva traz a história do empresário Ricardo, encontrado sem vida no estacionamento do prédio em que morava. A causa da morte? Um tiro na cabeça. O autor do disparo? Eis a questão que move a trama. Em um campo bastante amplo de suspeitos, fatos estranhos e poucas pistas, Espinosa precisa resolver o mistério.

Em um primeiro momento, Garcia-Roza aparenta fugir da estrutura tradicional do romance policial, no quesito "suicídio", que é a explicação real para a morte do empresário, porém, um crime real ocorre e o foco se direciona para ele, ou seja, temos uma nova composição criminal mais ampla, ainda se caracterizando como uma narrativa detetivesca e trazendo novos elementos para a trama.

Primeiramente, o leitor se depara com um narrador onisciente, apresentando o detetive Espinosa em sua rotina quando ocorre a morte do executivo. 0 espectador não imagina que tenha sido um suicídio e que a situação-problema da narrativa é, na verdade, um seguro de vida de 1 milhão de dólares, em meio a uma disputa: de um lado, dois trapaceiros tentando esconder o fato de ser suicídio, a fim de receber o dinheiro do seguro e, de outro, um funcionário corrupto da seguradora que precisa provar que foi suicídio, pois devido a lei, nesse caso, a família não teria direito ao seguro e ele lucraria uma boa comissão, salvando o seu emprego.

O assassino da trama é o funcionário da seguradora, um velho amigo de Espinosa. A surpresa causada ao descobrir o culpado é característica-chave do romance policial tradicional: o assassino é um daqueles de quem menos 
suspeitamos e está próximo ao detetive, crendo que o está enganando, enquanto, na verdade, está próximo de ser capturado.

Ainda, outras configurações da estrutura tradicional são encontradas no livro, uma delas é o companheiro do detetive na resolução dos casos. Espinosa conta com a ajuda de Weber, inspetor auxiliar da polícia, que o apoia na descoberta do criminoso. Dupin tinha seu amigo, com quem dividia a casa e o gosto pela literatura. É pela "voz" desse amigo que ele é apresentado em "Os assassinatos na Rua Morgue". Sherlock Holmes também deixou marcas dessa parceria investigativa, sobretudo com o bordão "elementar, meu caro Watson", ao se referir ao colega médico que o acompanhava nas inspeções. Não obstante, Poirot adentrou o universo detetivesco por intermédio de seu amigo capitão Hastings em O misterioso caso de Styles (1965).

Outra passagem que faz referência a Poe no livro de Garcia-Roza é a alusão ao conto "A carta roubada" (1844), já que na segunda parte de O silêncio da chuva o autor nomeia o capítulo 1 com o mesmo título do conto de Poe. Essa atitude pode ser considerada um tributo literário.

Nesse sentido, ao mencionar referências a obras de literatura policial presentes em $O$ silêncio da chuva, é interessante relembrar outro fragmento importante, que apresenta uma comparação de detetives ficcionais.

Nos filmes americanos, os policiais não ficam tão desamparados. 0 médico legista praticamente desvenda o crime para o detetive, este só tem que fazer uma perseguição espetacular pelas ruas de Nova York, São Francisco ou Los Angeles. Caso o legista falhe, há sempre a possibilidade de se enviar um fio de cabelo encontrado no local do crime para o FBI e no dia seguinte saberemos até por qual time de futebol seu proprietário torce. Aqui, neste aprazível Terceiro Mundo, o relatório do legista raramente informava se a vítima morrera por tiro ou por envenenamento. (GARCIA-ROZA, 2005, p. 89)

Nessa passagem, o inspetor Espinosa ironiza a condição do detetive no terceiro mundo, comparando-o aos dos Estados Unidos. Para ele, não se tem um sistema investigativo de qualidade no país que seja capaz de suprir as necessidades 
dos casos. $E$, enquanto faltam recursos, bons legistas e uma equipe competente, o trabalho do detetive se multiplica.

Percebe-se que há uma marca de verossimilhança na fala de Espinosa, pois há traços em sua reflexão nitidamente vinculados à realidade. Tanto na ficção, a partir da vida do detetive Espinosa, tendo como cenário o Rio de Janeiro, quanto na situação real e atual dessa cidade comprova-se a presença de centenas de casos não resolvidos.

Isso nos remete ao que destaca Piglia (1986) sobre o papel direcionado ao detetive literário: o de suprir a incompetência do sistema investigativo da vida real. Enquanto no mundo real, diversos casos são arquivados por falta de recursos para a investigação ou até mesmo de capacidade dos funcionários dos departamentos criminais, na literatura o detetive não tem essa opção. O seu dever não deixa dúvidas: persistir até encontrar os culpados.

Assim sendo, ao compararmos o detetive literário tradicional ou até mesmo "o detetive dos Estados Unidos", citado por Espinosa, ao próprio Espinosa, observamos que o protagonista da narrativa de Garcia-Roza já não é construído a partir do mesmo imaginário idealizado da capacidade surreal de resolução de problemas, como os detetives de Poe, Doyle e Christie. Espinosa tem consciência de suas limitações e das dificuldades do sistema investigativo de seu país. Ele entende que certas habilidades estão fora de seu alcance, contudo continua seguindo pistas e analisando os suspeitos, com base em sua dedução. Apesar de ocorrer pela falta de recursos para outros métodos e não por escolha, esse aspecto é primordial para que o caso da narrativa seja solucionado por ele, que é um gênio em sua época, a seu modo, dentro de seu limite.

É nisso que se encontra a essência da escrita de Garcia-Roza, o autor segue a linha tradicional da literatura policial, com as configurações já utilizadas por Poe, mas de uma forma não linear, adequando-as ao contexto de seu tempo e à sociedade a sua volta. Elas estão dispostas na trama em uma sequência diferente, pois o "crime' que inicia o livro na verdade era um suicídio e os verdadeiros assassinatos ocorrem da metade para o fim da trama. 
Ademais, a reflexão feita por Espinosa também pode ser vista enquanto um vestígio de metaliteratura, pois ele também se compara a outros personagens ficcionais. Não obstante, Mário Pontes (2007), ao trabalhar com as notas elementares da literatura policial, enfatiza que a própria literatura é um personagem da narrativa policial. Seja pela metaliteratura ou pelas referências que ela faz a outros autores.

\section{O jogo enigmático das iniciais: um labirinto de possibilidades}

Bernardo Carvalho nasceu em 1960 e assim como Garcia-Roza é carioca. Além de romancista, também é jornalista e tradutor. Na literatura é reconhecido, principalmente, por sua coletânea de contos Aberração (1995) e seu romance Nove noites (2002). O autor já recebeu prêmios como Portugal Telecom de Literatura Brasileira (2003), Associação Paulista de Críticos de Arte (APCA) (2005) e Jabuti (2004 e 2014).

Em sua obra, também destaca-se As iniciais (1999), livro que exige muita atenção do leitor, pois trata-se de um monólogo interior bastante reflexivo, no qual o narrador-personagem se afunda na angústia de um mistério que o perturba por anos. Ele narra a história a partir de sua visão analítica dos fatos e das pessoas envolvidas na situação enigmática que viveu.

Um detalhe notório, que realça a complexidade da leitura, é que na narrativa não são apresentados os nomes das personagens, apenas referem-se a elas pelas iniciais de seus nomes, como o próprio título do livro sugere. E, apesar de seguir uma ordem cronológica, a narrativa é composta por flashbacks ${ }^{9}$, que auxiliam na construção de uma camada de suspense e ansiedade.

A trama gira em torno de um jantar em um mosteiro abandonado, reservado a artistas realizado num mosteiro abandonado que se localiza num pequeno vilarejo. Doze pessoas se reúnem, dentre elas o narrador. Algumas compartilham ou apenas demonstram já terem vivido ou estarem vivendo situações perturbadoras. Há 
menção à uma doença, aos sintomas e à morte, dada como certa e esperada, por alguns dos convidados do jantar. No entanto, apesar de ser fortemente trazida para as reflexões do narrador, o que aumenta a tensão da narrativa - o nome da doença - não é revelado.

Durante o jantar, um dos convidados entrega ao narrador uma caixinha com as iniciais "VMDS" sem dizer nada a respeito. Desse momento em diante, ele se vê preso a esse mistério e coloca-se em uma posição de detetive, tentando juntar todas as pistas e analisar todas as personagens com as lembranças que possui daquele dia, para descobrir o que as iniciais significam. Observa-se novamente uma jogada do autor com o título do livro, agora em relação às letras da caixinha.

Dez anos se passam e, ainda perturbado com o mistério agoniante das iniciais, o narrador ainda carrega a caixinha em seu bolso e formula teorias, tentando juntar memórias e rastros a fim de entendê-los. Até que um dia encontra um personagem que estivera no mosteiro naquela noite intrigante. Uma esfera de suspense, fundamental nas narrativas detetivescas, é construída a partir desse possível reencontro.

O leitor que espera a revelação do significado das iniciais gravadas na caixinha, acaba se surpreendendo com o que na verdade é "revelado" de forma subentendida. Quando o narrador se aproxima do antigo conhecido, pronto para questionar o maior segredo que permeia em sua vida, escuta-o contar a história de um garoto que conheceu em viagens, o qual tomava todos os dias coquetéis de remédios.

Assim o livro é encerrado, não revelando claramente nenhuma informação, mas provocando reflexão sobre todas as pistas juntadas pelo narrador, principalmente, acerca da doença. Milena Magri (2016) aponta a aids como a doença mencionada no livro, levando em consideração as diversas metáforas encontradas, sendo uma delas a própria questão das iniciais.

Diversas possibilidades são deixadas em aberto, entretanto percebese que não são totalmente desconexa, pois há possíveis respostas para elas, dentro do próprio livro, que podem ser encontradas mediante pistas coletadas pelo narrador, que, ao procurá-las e analisá-las, incorpora o papel de detetive. É como se houvesse no final da história uma inversão de papeis: o "detetive" que 
permeou toda a narrativa seguindo os rastros agora entrega-os ao leitor, para que este, a partir deles, construa a sua própria reflexão e decifre o segredo.

Diferente das narrativas policiais tradicionais, o suspense em As Iniciais está na busca da definição das iniciais da caixinha ganhada pelo narrador e não na busca do assassino. Contudo, há diversos "suspeitos" de terem enviado a caixa e várias "trilhas" para o seu significado, bem como o narrador, que se enquadra na posição de detetive e as segue, gerando uma trama policial.

Desse modo, é possível caracterizar o romance de Carvalho (1999) como de cunho literário policial pelo campo investigativo e detetivesco que ele adentra. Mesmo a narrativa apresentando um final aberto e enigmático, sem a resolução final do caso, registram-se nela configurações detetivescas: o mistério, os suspeitos, as pistas, a investigação e, sobretudo, o detetive.

Nessa perspectiva, consideramos que o autor utiliza elementos da literatura policial tradicional, no entanto os dispõe na trama de uma maneira modificada, em especial, pela ordem não linear e o final abrupto e aberto, que pode ser analisado como uma referência à perturbação mental do narrador. Franco (2013) nota que o detetive, "[...] além de procurar unir as pistas como em um puzzle, precisa dar uma ordem a elas e, para tanto, a narrativa acaba sendo a ferramenta dessa compreensão" (FRANCO, 2013, p. 66).

Entretanto, como o narrador, apesar de coletar diversas pistas, não consegue dar uma ordem significativa propicia à compreensão, não há meios para um final esclarecido. Nesse momento, nota-se o fracasso do detetive, algo surpreendente, pois era inadmissível na narrativa policial moderna, devido à figura idealizada que se tinha do detetive. Na contemporaneidade isso é possível, pois há a humanização da personagem.

Franco (2013) denomina de "labirintos criminais" esses caminhos que o detetive percorre, para ela a narrativa policial se constrói dentro desse labirinto de elementos. Em As iniciais, muito mais do que labirintos criminais, observamos labirintos identitários, a partir de um jogo de identidades representadas por iniciais, as quais, tal como as identidades das personagens, não são decifradas. 
Além disso, enquanto Garcia-Roza (2005) alude a Poe, Carvalho (1999) menciona Agatha Christie em uma passagem do jantar, quando uma das convidadas conta a história de seu livro, que apresenta características policiais, e então outro convidado à mesa sugere: "[...] é uma espécie de Agatha Christie?" (CARVALHO, 1999, p. 58). Nessa fala, podemos observar que o autor demonstra ter conhecimento da estrutura narrativa de Agatha Christie. Ainda, pode-se considerar que a alusão refere-se à semelhança entre As iniciais e $O$ caso dos dez negrinhos (1939), no qual dez pessoas que cometeram crimes terríveis são convidadas para um jantar em uma ilha, onde cada uma é assassinada misteriosamente.

O caso dos dez negrinhos possui um final fechado, o qual deixa clara a descrição da morte de cada uma das personagens. Em As iniciais, diferente disso, temos um final aberto: não sabemos o destino certo da maioria das personagens, todavia tem-se a alusão à possível futura morte delas, devido à doença que perpassa a história. No livro de Agatha Christie o assassino era um juiz que estava aniquilando as pessoas devido aos crimes que elas cometeram anteriormente e saíram impunes, enquanto no livro de Bernardo Carvalho o antagonista seria quem enviou a caixinha ao narrador, no entanto a identidade dessa pessoa e a causa desse curioso presente não são revelados.

Chauvin (2017) considera O caso dos dez negrinhos um romance de ampulheta, pois os personagens vão sumindo pouco a pouco. O mesmo ocorre em As iniciais (1999), com a morte das personagens no decorrer dos anos devido à doença enigmática. Ademais, o autor aponta como característica fundamental no romance de Agatha Christie a questão da ênfase estar no enredo e não nos personagens. E, somente "à medida em que a situação se torna mais complexas, as criaturas entram em conflito consigo mesmas" (CHAUVIN, 2017, p. 85). Assim, observa-se que o enredo é que as move, e não o contrário, como se tudo já estivesse destinado a acontecer. Esses aspectos também são encontrados no romance de Carvalho (1999), pois a perturbação mental do narrador só ocorre a partir do enredo misterioso que o envolve e o empurra para dentro do mistério das iniciais da caixinha. 


\section{Configurações detetivescas modernas versus contemporâneas}

As configurações detetivescas da literatura policial tradicional, representadas, principalmente, por Agatha Christie, Conan Doyle e Edgar Allan Poe, ainda se fazem presentes nos dias de hoje, como observamos na análise de As iniciais e de O silêncio da chuva. Contudo, vêm sofrendo mudanças em certos aspectos, as quais, de acordo com Nebias (2010), são esperadas, pois representam um modelo de releitura que segue as transformações de sua época.

A necessidade do gênero policial de se reestruturar advém de uma imposição contemporânea que ultrapassa os limites da literatura. Como Nebias (2010) enfatiza, devido ao sistema investigativo precário do Brasil, ineficiente na maior parte dos casos criminais, fica bastante distante da realidade pensar em um detetive tão eficaz. Assim sendo, criou-se uma personagem mais humana. Não obstante, Albuquerque (1979) aponta que "o Brasil já tem uma literatura própria no gênero policial baseada em fatos verídicos" (ALBUQUERQUE, 1979, p. 217).

Para Nebias (2010), há uma reinvenção do detetive, pois, segundo a autora, "[...] o detetive clássico ou tradicional é o modelo de herói moderno, infalível, representante da ordem. Com o romance negro, surge um novo tipo de herói, mais próximo da realidade, mas que ainda representa a ordem" (NEBIAS, 2010, p. 7). Podemos comprovar isso ao lermos na trama de Garcia-Roza (2005), a partir do inspetor Espinosa, o qual expressa sentimentos, comete erros e até mesmo se envolve amorosamente com suspeitos do crime.

- Alguém vai Ihe acompanhar quando voltar para casa?

- Isso é um oferecimento?

- É uma preocupação, mas pode ser um oferecimento.

- Ninguém vai me acompanhar. Aceito sua oferta. Devo sair por volta das oito horas.

- Não saia antes de eu chegar.

Eram dez para as sei. Achei melhor sair antes que o tráfego em direção à zona sul ficasse engarrafado. No percurso fiz fantasias inconfessáveis. (GARCIA-ROZA, 2005, p. 89) 
O trecho selecionado é parte de uma conversa entre Espinosa e uma das suspeitas do crime que ele investigava, nota-se o interesse amoroso que o detetive nutria por ela, o que no romance policial tradicional seria inadmissível, pois o único comprometimento do detetive deveria ser com o mistério a ser solucionado.

Enquanto isso, na narrativa de Poe (2015), temos uma figura detetivesca absolutamente focada nos processos mentais de raciocínio que possibilitam a compreensão do caso e, consequentemente, seu esclarecimento. Essa é uma figura idealizada, imaginada como detentora de uma faculdade mental de difícil acesso ao homem comum, não é mera engenhosidade. Como destaca o narrador, é uma capacidade analítica restrita a poucos.

A capacidade analítica não deve ser confundida com a simples engenhosidade; pois embora o dono de uma mente analítica seja necessariamente engenhoso, o homem engenhoso é muitas vezes notavelmente incapaz de análise [...] Entre a engenhosidade e a capacidade analítica existe uma diferença ainda maior, na verdade, do que entre a fantasia e a imaginação, mas de caráter muito estritamente análogo. Verificar-se-á, com efeito que os dotados de engenho são sempre fantasiosos e que os verdadeiramente imaginativos nunca são outra coisa senão dados à análise. (POE, 2015, p. 304)

Nota-se que essa faculdade de resolução de Auguste Dupin é bastante distante da dos homens comuns. Ele é altamente idealizado, visto como dono de uma grandiosa capacidade dedutiva que o torna único, semelhante a um superherói de histórias de ação e até mesmo ao dândi, de Baudelaire. Por mais que possa haver traços de engenhosidade em outros homens, esta, de acordo com o narrador, não deve, sob hipótese alguma, ser comparada à tamanha magnitude inteligível de Dupin.

Baudelaire (1996) apresenta o dândi como um homem de altíssimo padrão estético, gosto refinado e intelectual. Essa figura se aproxima muito do detetive tradicional, Auguste Dupin, que tinha um vocabulário rebuscado, andava pelas ruas de Paris apenas à noite, a fim de observar mais poeticamente o espaço, e frequentava as livrarias e bibliotecas mais elegantes da cidade, sempre em busca de livros para leitores de grau intelectual elevado. 
Por outro lado, Espinosa anda pelos bairros do subúrbio do Rio de Janeiro, fala palavras de baixo calão, compra seus livros no sebo da esquina, almoça no McDonald's, sofre por amor e, apesar de conseguir encontrar pistas no mistério que segue, não consegue decifrá-las apenas analisando-as mentalmente. Sua inteligência tem limites, seus raciocínios não são peculiares. É um personagem próximo ao homem comum.

Pode-se pensar, então, que a principal diferença entre o detetive de Poe (2015) e o de Garcia-Roza (2005) é que o primeiro é idealizado enquanto o segundo é humanizado. Percebemos que as características deles são semelhantes às suas respectivas épocas. Enquanto na primeira, pedia-se à literatura que criasse o homem ideal, a fim de suprir as lacunas do real, na segunda sugere-se que o detetive se aproxime da realidade para que se possa dar credibilidade às suas palavras e atos.

No que condiz ao detetive contemporâneo de Bernardo Carvalho (1999), é relevante destacar primeiramente "o que é o contemporâneo". O filósofo italiano Giorgio Agamben (2009) evidencia que é realmente contemporâneo aquele que não se adequa ao seu tempo, ou seja, que é inatual, mas que justamente por isso é capaz de compreender muito melhor a época em que vive. Dessa maneira, o autor sublinha que "[...] a contemporaneidade, portanto, é uma singular relação com o próprio tempo" (AGAMBEN, 2009, p. 57). Para ele, quem se adapta muito bem à época em que vive não pode ser nunca considerado contemporâneo, pois não conseguem realmente compreendê-la.

Nesse sentindo, em As iniciais, observamos a presença de um detetive contemporâneo. O narrador-personagem que se coloca no papel de detetive é uma figura desajustada dos padrões de sua época, é um escritor peculiar, com perturbações significativas, passando por uma crise existencial de identidade.

Ainda, em Poe (2015) e Garcia-Roza (2005), temos o que se encaixa na configuração whodunnit? ${ }^{10}$, que é iniciada pelo assassinato de um personagem

10 Termo abreviativo do inglês "who has done it?", que pode ser interpretado como "quem matou?". É um conceito das narrativas policiescas que surge com Poe em "Os crimes da Rua Morgue" (1841) e consiste no assassinato de uma das personagens e no processo investigativo para descobrir quem o matou. 
relevante e seguida por uma trilha alegórica de indícios, acusados e segredos. No final (fechado), apresenta-se a solução do mistério, bem como todas as respostas para as questões lançadas anteriormente.

Já em Carvalho (1999), temos a percepção noir ${ }^{11}$, construída a partir de uma camada de suspense, com flashbacks e muitas reflexões por parte do narrador ou personagens. Nas narrativas de noir não é necessário haver uma resolução completa do mistério, como constata-se em As iniciais, que tem um final aberto.

De acordo com Nebias (2010), pensar nessa transgressão da narrativa policial tradicional para a de noir, implica, portanto, pensar na mudança da resolução pelo método dedutivo tradicional para a ação real. Verifica-se isso em As iniciais a partir do caso não resolvido da definição das iniciais da caixinha recebida pelo narrador. Ao contrário do detetive clássico, o contemporâneo não consegue solucionar o mistério apenas com o "poder dedutivo de sua mente", é necessária a ação. Podemos classificar como ação, o momento em que o narrador, na posição de detetive, se dirige àquele que ele crê ter visto na noite em que recebeu o objeto, para questioná-lo a respeito dos ocorridos no jantar do mosteiro.

Ricardo Piglia (2004) destaca que um conto, sempre conta duas histórias, já Tzvetan Todorov (1970), por sua vez, pensou na questão da dualidade de histórias da narrativa policial, evidenciando que esta também é construída por duas histórias, sendo a primeira a do crime, ou de algo que precisa ser esclarecido, e a segunda toda a jornada em busca do desvendamento da primeira.

Na base do romance de enigma encontramos uma dualidade, e é ela que nos vai guiar para descrevê-lo. Esse romance não contém uma, mas duas histórias: a história do crime e a história do inquérito[...] Podemse ainda caracterizar essas duas histórias dizendo que a primeira, a do crime, conta "o que se passou efetivamente", enquanto a segunda, a do inquérito, explica como o leitor (ou o narrador) tomou conhecimento dela. (TODOROV, 1970, p. 94-95) 
Essa configuração da literatura policial é vista tanto no romance contemporâneo, a partir de Garcia-Roza (2005) e Carvalho (1999), quanto no romance moderno, de Poe (2015). Ambos apresentam inicialmente um nó (primeira história), que precisa ser desenrolado para entender o que realmente aconteceu (segunda história ou história debaixo). O que liga uma a outra é a investigação.

Poe (2015) traz a história do curioso assassinato de mãe e filha na rua Morgue em primeiro plano, e em um segundo, pelas mãos de Dupin, o caso é desvendado, revelando que na verdade o assassino é um gorila que fugiu do dono e enraivecido comete o delito.

Da mesma maneira, Garcia-Roza (2005), em um momento inicial, lança o tema de um possível assassinato de um milionário e, no final, descobre-se que na verdade foi suicídio. Carvalho (1999) apresenta como primeira história a entrega da caixinha ao narrador e como segunda a busca do sentido do "presente".

Contudo, quem melhor constrói essa estrutura tradicional da narrativa policial é a "dama do crime", Agatha Christie. A autora utiliza uma escrita objetiva, mas de tamanho magnetismo que chega a ser quase que hipnótica. Logo no início de seus livros, joga ao leitor a trama: um assassinato, alguns suspeitos e poucas pistas, como primeira história; na segunda, é que entra o detetive, na maioria de seus casos, Hercule Poirot e Miss Marple. A partir dessa figura detetivesca toda a segunda história é percorrida, debruçando-se nos fatos e indícios deixados pelo criminoso, e ao final temos a resolução do mistério, a resposta para a pergunta "quem matou?".

Dessa forma, pode-se inferir que enquanto o detetive Poirot e o Espinosa estão exercendo sua profissão, Miss Marple, Dupin, e o narrador de Carvalho estão momentaneamente posicionados com o "cargo" detetivesco. No entanto, observa-se que ambos apresentam as características primordiais do detetive: a determinação para resolver o enigma que os cerca.

\section{Considerações finais}

A narrativa policial brasileira contemporânea se reinventa constantemente, de acordo com o desenvolvimento da sociedade, atingindo caráter verossímil e, 
sobretudo, desdobrando-se pelas linhas roman noir e whodunnit. Dessa forma, traz as configurações detetivescas criadas por Edgar Allan Poe, em 1841, e posteriormente seguidas por Conan Doyle e Agatha Christie, porém de maneira atualizada, considerando o contexto de sua época.

Partindo dessa análise e da comparação feita a partir das configurações detetivescas do romance policial tradicional ou clássico, advindo do modernismo, ao contemporâneo brasileiro, representado aqui por Bernardo Carvalho e Luiz Alfredo Garcia-Roza, constatou-se que, enquanto os detetives literários modernos eram idealizados, vistos como grandes heróis perfeitos, os contemporâneos são humanizados, já que nem sempre conseguem desvendar os casos criminais sozinhos, o que faz jus ao detetive da vida real, que pode errar e necessita de auxílio. Todavia nota-se que, mesmo que as personalidades e características das personagens - assim como os aspectos das configurações detetivescas - se diferenciem parcialmente entre o moderno e o contemporâneo, ainda há detetives, casos enigmáticos, pistas e suspeitos, os quais são considerados os grandes marcos iniciais de toda a sequência policial.

Em parte, não sabemos mais diferir com precisão vítimas e vilões, pois como forma de reflexo da sociedade, que é heterogênea, quebrou-se o paradigma da totalidade do caráter das personagens. Nesse sentido, os romances de detetive mostram que todos têm segredos a serem desvendados, independentemente de serem ou não os culpados do problema inicial da trama, o que prova que o caráter de crítica social, explícito no gênero policiesco desde a sua inauguração, ainda está presente. Portanto, a grande essência da literatura policial permanece!

\section{Referências}

AGAMBEN, G. O que é o Contemporâneo? In: AGAMBEN, G. O que é o Contemporâneo? e outros ensaios. Tradução: Vinícius Nicastro Honesko. Chapecó: Argos, 2009. p. 55-73. 
ALBUQUERQUE, P. M. O mundo emocionante do romance policial. Rio de Janeiro: Francisco Alves, 1979.

BAUDELAIRE, C. Sobre a modernidade. Tradução: Teixeira Coelho. São Paulo: Paz e Terra, 1996.

BENJAMIN, W. Charles Baudelaire: um lírico no auge do capitalismo. Tradução: José Martins Barbosa. São Paulo: Brasiliense, 1991.

CALVINO, I. Para que ler os clássicos? In: CALVINO, I. Por que ler os clássicos. Tradução: Nilson Moulin. São Paulo: Companhia das Letras, 1993. p. 9-16.

CARVALHO, B. As iniciais. São Paulo: Companhia das letras, 1999.

CHAUVIN, J. P. Crimes de festim: ensaios sobre Agatha Christie. São Paulo: Todas as Musas, 2017.

FRANCO, A. A. Labirintos perdidos: ficção contemporânea em trânsito nos romances de Bernardo Carvalho e Francisco José Viegas (2000-2010). 2013. Tese (Doutorado em Letras) - Universidade de São Paulo, São Paulo, 2013.

GARCIA-ROZA, L. A. O silêncio da chuva. São Paulo: Companhia das Letras, 2005.

MAGRI, M. M. Figurações da AIDS em As Iniciais, de Bernardo Carvalho. Via Atlântica, São Paulo, n. 29, p. 445-460, 2016.

NEBIAS, M. M. R. A reinvenção do detetive em tempos pós-utópicos. Fólio: Revista de Letras, Rio de Janeiro, v. 2, n. 2, p. 9-20, 2010. 
PIGLIA, R. Formas breves. Tradução: José Marcos Mariani de Macedo. São Paulo: Companhia das Letras, 2004.

PIGLIA, R. Sobre el género policial. In: PIGLIA, R. Crítica y ficción. Buenos Aires: Lectulandia, 1986. p. 32-34.

POE, E. A. Contos de imaginação e mistério. Tradução: Cássio de Arantes Leite. São Paulo: Tordesilhas, 2015.

POE, E. A. Poemas e ensaios. Tradução: Oscar Mendes e Milton Amado. São Paulo: Globo, 1999.

PONTES, M. Elementares notas sobre a história da literatura policial. Rio de Janeiro: Odisseia, 2007.

REIMÃO, S. L. O que é romance policial. São Paulo: Brasiliense, 1983.

REIMÃO, S. L. Literatura policial brasileira. Rio de Janeiro: Zahar, 2005.

TODOROV, T. Tipologia do romance policial. In: TODOROV, T. As estruturas narrativas. Tradução: Leila Perrone-Moisés. São Paulo: Perspectiva, 1970. p. 93-104.

submetido em: 15 ago. 2019 | aprovado em: 17 dez. 2019 